6. Полат Е. С. Новые информационные технологии в системе образования : [учеб. пособ. для студ. пед. вузов и системы повыш. квалиф. пед. кадров] ; под ред. Е. С. Полат и др. - М. : Изд. Центр «Академия», 1999. - 224 с.

7. Фунтікова О.О. Сучасний погляд на використання методу проектів в організації самостійної роботи студентів поза аудиторією у вищій школі / О. О. Фунтікова // Педагогіка, психологія та медико-біологічні проблеми фізичного виховання і спорту. 2003. - № 11. - С. 17-24.

Стаття надійшла до редакції 12.05.2012 p.

УДК 372.874

В. Ю. Цісарук, асистент, Кременеџький обласний гуманітарно-педагогічний інститут ім. Тараса Шевченка

\title{
СТАН ТА СТРУКТУРА ГОТОВНОСТІ ВЧИТЕЛІВ ТЕХНОЛОГІЙ ДО НАВЧАННЯ ШКОЛЯРІВ МИСТЕЦТВУ ХУДОЖНЬОГО ОБРОБЛЕННЯ ДЕРЕВИНИ
}

Цісарук В. Ю. Стан та структура готовності вчителів технологій до навчання школярів мистеитву художнього оброблення деревини.

У статті визначено стан готовності вчителів технологій до навчання школярів у галузі художнього оброблення деревини та обтрунтовано структура иієї готовності. Перевірено та описано рівень готовності педагогів загальноосвітніх шкіл Львівської та Тернопільської областей.

Ключові слова:технології, готовність, учитель.

Цисарук В. Ю. Состояние и структура готовности учителей технологии к обучению школьников искусству художественной обработки древесиньл.

B статье определяется состояние готовности учителей технологий $\kappa$ обучению школьников в области художественной обработки древесины и обосновывается структура этой готовности. Проверен и описан уровень готовности педагогов общеобразовательных икол Львовской и Тернопольской областей.

Ключевые слова: технологии, готовность, учитель.

Tsisaruk V. State and structure of teachers' technology readiness to learn the art school art wood processing.

In the article a ready of teachers of technologies condition is determined to the studies of schoolchildren in industry of artistic treatment of wood and the structure of this readiness is grounded. The level of readiness of teachers is tested and described ingeneral lines educational schools of the Lviv and Ternopil areas.

Key words: technologies, readiness, teacher.

Постановка проблеми. У професійно-педагогічній підготовці майбутніх учителів технологій вагоме місце, з-поміж інших, посідає оволодіння різними видами декоративно-ужиткового мистецтва, зокрема художнього деревооброблення. Культурологічний, гуманістичний підхід у вищій педагогічній освіті $€$ невід'ємною складовою методології гармонійного розвитку особистості вчителя як загальнолюдської і професійної цінності [4]. У поєднанні 3 загальнонауковою, мистецтвознавчою, політехнічною, економічною, екологічною освітою та суспільнокорисною практикою художньо-трудова підготовка у галузі оброблення деревини забезпечує гармонічний розвиток, охоплюючи інтелектуальні, емоційні, вольові, ціннісно-орієнтаційні, творчі аспекти формування особистості майбутнього педагога. 
Мета статті - визначити стан готовності вчителів технологій до навчання школярів у галузі художнього оброблення деревини та обгрунтувати структуру цієї готовності.

Виклад основного матеріалу. Задля виявлення стану готовності вчителів технологій у галузі художнього оброблення деревини та навчання школярів цього виду декоративно-ужиткового мистецтва упродовж 20092010 н.р. нами проводилося анкетування педагогів загальноосвітніх шкіл Львівської та Тернопільської областей.

3-поміж 129 учителів технологій, які брали участь в опитуванні, 76,4 \% мали вищу педагогічну освіту, $17,5 \%$ - вищу технічну освіту, решта $6,1 \%$ середню спеціальну освіту, здебільшого професійно-технічну. До 5 років стажу роботи в навчальних закладах мали $16,2 \%$ педагогів, від 5 до 10 років 24,5\%, від 10 до 15 років - 9,1\%, від 15 до 25 років - 36,8 \%, пенсіонерів зі стажем понад 25 років - 13,4\%.

Аналіз сучасної шкільної практики засвідчив суперечності, що склалися між рівнем вимог соціуму до вчителя технологій та станом професійної підготовленості студентів до майбутньої педагогічної діяльності. Це зумовлено тим, що мета і завдання технологічної освіти учнів, незважаючи на здавалося б особливу привабливість, не знайшли належного застосування в шкільній практиці. Нагадаємо, що згідно з наказом Міністерства освіти i науки України від 05 лютого 2009 р. за № 66 у 5, 6, 9 класах основної школи передбачено 1 год. на тиждень, у $7-8$ класах - 2 год.; у 10 класах старшої школи (незалежно від профілю) згідно з наказом від 10 серпня 2010 р. за № 1/9 - 543 передбачено 1 год. на тиждень, у цих же класах технологічного профілю - 6 год., а за наказом № 306 від 20 травня 2003 р. в 11 класах універсального профілю відводиться 2 год., на технологічний профіль - 5 $(+1)$ год. на тиждень. Це здавалося мало б активізувати трудову підготовку школярів, однак рангування відповідей учителів на питання анкети засвідчило, що популярність шкільного предмета «Трудове навчання» та технологічного профілю у старших класах $є$ достатньо низькою, адже зумовлено такими чинниками:

1) невиправданим скороченням у базовому навчальному плані школи годин на вивчення предмета «Трудове навчання» (передовсім у 5, 6, 9 класах) та ігноруванням шкільними адміністраціями технологічного профілю у старших класах - 29,2 \% респондентів;

2) відсутністю оригінальних дидактичних і методичних матеріалів 3 вивчення сучасних технологій, нового навчального обладнання, інструментів, матеріалів, сучасних засобів навчання тощо - 26,8 \%;

3) гострою нестачею нової генерації вчителів технологій з високим рівнем фахової компетентності, що пов'язано з недостатньою якістю їхньої підготовки у педагогічних ВНЗ та низьким рівень оплати вчительської праці - 19,5 \%;

4) недооцінювання керівництвом системи освіти ролі та значення освітньої галузі «Технології», що зумовило непослідовність та хаотичність змін, які спостерігалися останніми роками в цій сфері - 11,6\%; 
5) відсутністю сучасного теоретико-методологічного підгрунтя та механізмів практичної реалізації напрямів розвитку технологічної освіти в руслі іiі відповідності загальнонаціональним інтересам та міжнародним тенденціям - 7,7\%;

6) припиненням взаємодії педагогічних колективів із підприємствами та господарствами, які надавали школам шефську допомогу i частково вирішували проблему професійної орієнтації та профільного навчання школярів $-5,2 \%$.

Учителі також зазначали, що ці проблеми призвели до відтоку педагогічних кадрів, особливо чоловіків, морального та фізичного старіння навчально-матеріальної бази, а в окремих шкіл - до іiі знищення та заміни занять 3 технологій вивченням інших предметів, що є грубим порушенням засад Базового навчального плану школи та руйнуванням єдиного освітнього простору. 3 іншого боку, на думку учителів, упровадження освітньої галузі «Технології» призвело до появи низки помітно змінених концептуальних і методичних трактувань iі предметного змісту. За цих умов, у багатьох загальноосвітніх школах навчання «матеріальних» технологій учнів 5-9 класів заміщується викладанням комп'ютерних технологій, що призводить до підміни реального світу творчої діяльності екранним, віртуальним світом. Водночас у старших класах вже нині технологічний профіль за «престижністю» значно поступається іншим профілям та навчальним предметам. Отже, учнів шкіл навмисно орієнтують лише до вступу на гуманітарні спеціальності ВН3, незважаючи на загальні тенденції та характер регіонального ринку праці і професій.

Щодо побудови структури та змісту освітньої галузі «Технології», то головними аспектами вчителі вважають сучасне розуміння сутності і змісту цієї галузі наукового знання та творчої діяльності людини $(79,7 \%$ респондентів). Зокрема, вони зазначають, що, незважаючи на істотну динаміку зміни змісту технологічної освіти, за останні 20 років шкільний предмет «Трудове навчання» переживає зміну вже третього покоління свого змісту - педагогічна наука, а звідси й школа далі знаходяться в полоні застарілих поглядів, про що свідчить недосконалість структури та змісту навчальної програми для 5-9 класів [1], рекомендованої МОН України 27 серпня 2010 р. (наказ за № 1/11-8205).

Анкетування і бесіди з учителями також дозволили виявити, що одним 3 головних недоліків технологічної освіти є віддаленість традиційного змісту від інтересів сучасної молоді. Чимало вчителів (62,5\%) зазначало, що потрібні принципово нові підходи до визначення змісту технологічної освіти, які грунтуються на творчості. Для активного і повноцінного життя учням потрібні не лише знання, а, може, і найбільше, творчі можливості у розв'язанні проблем та досвід творчої діяльності. Зрештою, інформацію завжди можна віднайти та засвоїти, якщо вона виявиться потрібною для творчої діяльності. Тому важливою педагогічною умовою учителі технологій 
вважають зменшення питомої ваги готової інформації, а зростання частки творчої діяльності, що забезпечує розвивальне і виховне навчання.

У цьому контексті вчителі технологій позитивно відзначили зміст навчальної програми «Трудове навчання: основи дизайну» для загальноосвітніх навчальних закладів нового типу: ліцеїв, гімназій, коледжів (5-9 класи), рекомендованої МОН України 25 липня 2010 року (наказ за № 1/11-3179) [3]. Вони активно підтримували тезу про те, що зміст технологічної освіти, особливо в основній школі, має визначатися 3 художньо-творчим ухилом, який відповідає психофізіологічним особливостям розвитку учнів цієї вікової категорії.

Важливим для проблеми дослідження виявилися такі результати: більшість учителів технологій (74,3\% респондентів) обирають 3 типової навчальної програми для 5-9 класів [1] варіативні модулі, спрямовані на навчання школярів технологій виготовлення декоративно-ужиткових виробів. Так, у галузі художнього оброблення деревини серед учнів 5-6 класів найпопулярнішими $\epsilon$ такі варіативні модулі: «Художнє випалювання» 42,3 \%, «Виготовлення дерев'яної іграшки» - 34,2 \%, «Ажурне випилювання» 30,4 \%, «Аплікація 3 природних матеріалів (соломки)» - 13,1 \%. Учні 7-9 класів здебільшого обирають такі варіативні модулі: «Різьблення деревини» $38,5 \%$, «Токарне оброблення деревини» - 36,4\%, «Мозаїка на деревині (маркетрі)»-11,8\%, «Інтарсія, інкрустація» - 7,2 \%, «Плетіння з природних матеріалів (лози)» $-6,1 \%$ респондентів.

Зазначимо, що нова навчальна програма «Технології. 10-11 класи» [2] для універсального профілю також має модульну структуру і складається 3 двох частин - інваріантної та варіативної. Основою інваріантного складника є базовий модуль «Проектні технології в перетворювальній діяльності людини», на вивчення якого відводиться по 12 годин. Опанувавши базовий модуль, старшокласники використовують проектну технологію як інструмент для розв’язання проблем творчого характеру. Із цією метою їм пропонуються варіативні модулі, з-поміж яких у хлопців найпопулярнішими є: «Технологія дизайну інтер'єру» - 26,3 \%, «Технологія дизайну шкільних та офісних меблів» - 20,5\%, «Технологія токарного оброблення деревини» $16,9 \%$, «Технологія художнього різьблення по дереву» - 12,4\%, «Технологія геометричного гострокутного гуцульського різьблення» - 9,2 \%, «Технологія рельєфного різьблення» - 5,9\%, «Технологія інкрустації виробів 3 деревини» - 4,3\%, «Технологія художнього оброблення деревини випилюванням» - 2,8\%, «Технологія пірографії (випалювання) на деревині» $1,7 \%$ респондентів. Серед старшокласників, які навчаються за технологічним профілем, найзапитанішими є «Основи дизайну» - 32,3 \%, «Технологія художньої обробки матеріалів (деревини)» - 24,5\% та «Технологія деревообробки» - 16,1%; решта - 27,1 \% інші спеціалізації.

В окремих випадках, у межах технологічного профілю навчання, здійснюється допрофесійна підготовка старшокласників у галузі художнього оброблення деревини, зокрема у Львівській (Бориславський МНВК, 
Дрогобицька ЗСШ № 14, Стрийська ЗСШ № 10, Сколівська ЗСШ № 1, ЗСШ селища Івано-Франкове Яворівського району та ін.) та Тернопільській (Кременецькі ЗСШ №3, №4, №5, Горинська ЗСШ, Староолексинецька ЗСШ, Лопушенська ЗСШ Кременецького району та ін.) областях.

Рівень підготовленості до проведення занять 3 художнього оброблення деревини вчителі технологій оцінили так: 41,6 \% вважають себе достатньо підготовленими до цього виду декоративно-ужиткового мистецтва (особливо 3 учнями 5-9 класів), решта 58,4\% - вказали на недостатність своєї художньо-трудової підготовки, зумовлений низьким рівнем викладання в педагогічних ВН3 (зазначимо, що більшість 3 опитаних педагогічних працівників (89,6 \%) опановували фах 15-25 років тому).

На думку педагогів, забезпеченість загальноосвітніх шкіл спеціальною літературою з художнього оброблення деревини $\epsilon$ вкрай недостатньою, а в окремих випадках вона взагалі відсутня. На жаль, позитивну відповідь щодо повної забезпеченості цією літературою не дав жоден з опитуваних учителів; 43,9 \% респондентів вказали на наявність відповідної літератури у домашній бібліотеці. Серед фахової періодичної преси, у якій часто публікуються статті, пов'язані 3 художнім деревообробництвом, найкращими за змістом, інформаційним та методичним наповненням учителі технологій визнали такі: журнали «Трудова підготовка в закладах освіти» видавництва «Педагогічна преса» - 76,1 \% та «Трудове навчання в школі» видавничої групи «Основа» $14,5 \%$; газета «Трудове навчання» видавництва «Шкільний світ» - 9,4\%.

Ряд учителів $(28,3$ \%) навчальну інформацію з художнього оброблення деревини здебільшого знаходить в Інтернеті, а серед найпопулярніших сайтів визначають такі: 1) http://trudove.org.ua - 52,5\%; 2) www.trudovik.narod.ru $24,1 \%$; 3) www.lobzik.pri.ee - 12,6\%; 4) http://trud.mp.minsk.edu.by - 5,2\%; 5) http://e-kniga.in.ua/category/trudovoe-obuchenie/ - 3,4 \%; 6) http://school.xvatit.com $2,2 \%$ та ін.

Відрадно, що майже всі опитані вчителі технологій $(94,6$ \%) вважають, що уроки трудового навчання мають найкращі можливості для здійснення творчої художньо-трудової діяльності школярів, зокрема для хлопців у галузі художнього оброблення деревини.

Анкетування 62 викладачів факультетів підготовки вчителів технологій Дрогобицького, Тернопільського, Уманського педагогічних університетів та Кременецького обласного гуманітарно-педагогічного інституту імені Тараса Шевченка (59,6\% мали вчені ступені та звання) засвідчило, що 91,5\% респондентів підтримує поглиблене вивчення у навчально-виробничих майстернях мистецтва художнього оброблення деревини, передовсім сучасних формотворчих і декоративних технік. На питання щодо компетентності у галузі декоративно-ужиткового мистецтва та необхідності включати його елементи під час викладання інших навчальних дисциплін позитивну відповідь дали лише 33,4 \% викладачів.

На констатуального етапі педагогічного експерименту задля вивчення рівня підготовленості майбутніх учителів технологій у галузі художнього 
оброблення деревини та навчання школярів цього виду декоративноужиткового мистецтва нами здійснювалося анкетування студентів вище зазначених педагогічних ВНЗ. Для цього була розроблена анкета закритого типу, у якій питання містили прямі та непрямі відповіді, передбачали декілька відповідей або позитивні («так») чи негативні відповіді («ні»), за якими респондентам необхідно було зробити короткий висновок. В анкеті пропонувалися нескладні питання (щодо конкретних дій, фактів, явищ тощо) або підвищеної складності (передбачали рефлексію, об’єктивну самооцінку), водночас питання не потребували моральних чи соціальних оцінок.

В анкетуванні брали участь 216 студентів випускних курсів ОКР «Бакалавр» та «Спеціаліст». На запитання «Чи вважаєте важливим здійснення професійно-педагогічної підготовки у галузі декоративноужиткового мистецтва, зокрема художнього оброблення деревини?» 84,5\% респондентів відповіли - «так», решта 15,5\% - «ні». Розкрити дефініцію «творча художньо-трудова діяльність» змогли лише 12,6\%, інші - дали неповні або неправильні відповіді, що не відображали сутності цього поняття. На запитання, яке відображає системність набутих студентами знань й умінь: «Чим, на Ваш погляд, визначається рівень підготовленості у галузі художнього оброблення деревини та навчання школярів цього виду декоративно-ужиткового мистецтва» 96,3\% не змогли дати усвідомленої відповідь. Серед формотворчих та декоративних технік художнього деревообробництва, якими оволоділи студенти на заняттях у навчальновиробничих майстернях педагогічного ВНЗ, вони здебільшого називали: столярство (100\%), токарство (100\%), геометричне різьблення $(76,3 \%)$, випалювання $(37,2 \%)$, розпис $(12,6 \%)$, рельєфне різьблення $(6,4 \%)$, інтарсію і мозаїку $(4,7 \%)$.

Рефлектуючи, студенти на запитання про те, наскільки вважають себе теоретично підготовленими до здійснення навчання школярів художнього оброблення деревини, дали такі відповіді: «повністю готові» - 12,3\%; «достатньо готові» - 33,4 \%; «частково готові» - 39,8 \%; «не готові» - 14,5\%. Стосовно практичної підготовленості студентів до цієї ж діяльності отримані дещо вищі показники («повністю готові» - 21,2\%; «достатньо готові» 41,9\%; «частково готові» - 30,5\%; «не готові» - 6,4\%), які свідчать про певний дисбаланс між теоретичним і практичним складниками художньотрудової підготовки майбутніх учителів у галузі художнього деревообробництва.

Причина проблем недостатнього рівня готовності студентів до здійснення навчання школярів художнього оброблення деревини для 46,3\% респондентів вбачається у недостатньому рівні художньо-трудової та методичної підготовки у ВН3; 27,3\% студентів вважають недостатніми самоорганізацію в позааудиторний час, самоосвіту та самовдосконалення в обраній творчій діяльності; решта 26,4 \% - вказують на обидві вище зазначені причини та інші, пов'язані здебільшого з особистісними чинниками.

У набутті соціально-гуманітарних знань з історії, мистецтвознавства, етнографії, краєзнавства тощо вбачають потребу 5,3\% респондентів, 
художньо-проектну і техніко-технологічну допомогу потребують - 14,3 \%, а психолого-педагогічну, дидактичну та методичну - 35,6\%; решта 44,8 \% студентів висловилися за комплексну допомогу з усіх вище зазначених галузей наукових знань.

Необхідність вивчення технології художнього деревообробництва як додаткової навчальної дисципліни за вибором студента підтримують 84,6\% респондентів, а серед ефективних шляхів та засобів підвищення рівня підготовки у галузі художнього оброблення деревини і навчання школярів цього виду декоративно-ужиткового мистецтва ними були обрані такі: підвищення науково-методичного рівня лекційних і практичних занять $-43,8 \%$; участь у роботі проблемних груп, предметних гуртків, науково-педагогічних дослідженнях тощо - 22,9\%; удосконалення організації та проведення педагогічних і технологічних практик - 19,7 \%; інші пропозиції-13,6\%.

Отримані результати дозволяють констатувати, що в шкільній практиці не ведеться системної, цілеспрямованої роботи 3 організації на високому науково-практичному рівні занять 3 художнього оброблення деревини, що зумовлено низкою причин, зокрема: наявністю у вчителівпрактиків поверхових знань (соціально-гуманітарних, художньо-проектних, техніко-технологічних, психолого-педагогічних, дидактико-методичних) у досліджуваній галузі; недостатнім рівнем практичної підготовки у царині проектування i виготовлення декоративно-ужиткових виробів 3 дерева; відсутністю вмінь здійснювати моніторинг творчої художньо-трудової діяльності учнів; небажанням педагогів займатися самоосвітою, підвищенням своєї кваліфікації тощо. Водночас, реальний рівень підготовки майбутніх учителів технологій до організації творчої художньо-трудової діяльності в школі можна вважати таким, що не відповідає сучасним вимогам.

Аналіз стану й узагальнення різних науково-теоретичних підходів розуміння готовності вчителя технологій до професійно-педагогічної діяльності у галузі декоративно-ужиткового мистецтва (художнього оброблення деревини) дозволяе виокремити в ऑiі структурі такі основні взаємозв'язані компоненти (див. рис. 1): мотиваційний, когнітивний, процесуальний та оцінно-рефлексивний.

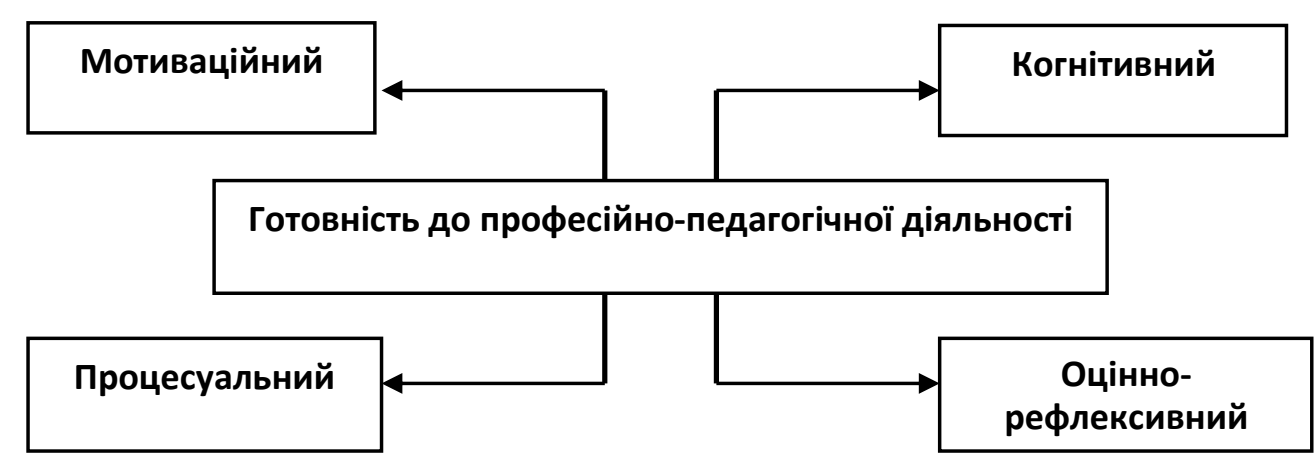

Рис. 1. Структура готовності майбутніх учителів технологій до професійно-педагогічної діяльності у галузі декоративно-ужиткового мистеитва 
Висновки. Вивчення стану шкільної й університетської практики дозволяє дійти висновку, що формування готовності майбутніх учителів технологій до навчання школярів декоративно-ужиткового мистецтва (зокрема, художнього оброблення деревини) є однією з важливих передумов цілеспрямованої професійно-педагогічної діяльності, а процес формування цієї готовності у ВНЗ має бути системним, методологічно й дидактично обгрунтованим.

\section{Література}

1. Навчальна програма. Трудове навчання 5-9 класи. Нова редакція / укл.: Н. І. Боринець, В. М. Гащак, Р. М. Лещук, В. М. Мадзігон та ін. [Електронний ресурс]. Режим доступу : http://trudove.org.ua/ post/nova-redakts-ya-programi-var-ativn-modul.

2. Навчальна програма «Технології. 10-11 класи» / укл. Н. І. Боринець, С. М. Дятленко, В. К. Сидоренко, Г. В. Терещук та ін. [Електронний ресурс]. - Режим доступу : http://trudove.org.ua/ post/ programi- modul.

3. Навчальна програма «Трудове навчання: основи дизайну» для загальноосвітніх навчальних закладів нового типу: ліцеїв, гімназій, коледжів (5 -9 класи) // Трудова підготовка в закладах освіти. - 2010. - № 9. - С. 13-34; № 10. - С. 29-48; № 11-12. - С. 11-30.

4. Оршанський Л. В. Художньо-трудова підготовка майбутніх учителів трудового навчання : [монографія] / Леонід Володимирович Оршанський. - Дрогобич : Швидко Друк, 2008. -278 с.

Стаття надійшла до редакції 29.05.2012 p.

I. В. Цісарук, асистент, Кременеиький обласний гуманітарно-педагогічний інститут ім. Тараса Шевченка

\section{ОСНОВНІ ПІДХОДИ ДО ПРОБЛЕМИ ОРГАНІЗАЦІЇ ТА ПІДГОТОВКИ САМОСТІЙНӦ̈ РОБОТИ МАЙБУТНІХ УЧИТЕЛІВ ТЕХНОЛОГІЙ}

Цісарук I. В. Основні підходи до проблеми організачії та підготовки самостійної роботи майбутніх учителів технологій.

У статті розкрито основні підходи до проблеми організації самостійної роботи майбутніх фахівиів, проаналізовано роль самостійної роботи на практичних заняттях технологічних дисциплін.

Ключові слова: самостійна робота, практичні заняття, студент, самореалізація.

Цисарук И. В. Основные подходы к проблеме организаџии и подготовке самостоятельной работы будущих учителей технологии.

В статье раскрываются основные подходы к проблеме организачии самостоятельной работы будущих специалистов, проанализирована роль самостоятельной работы на практических занятиях технологических дисицилин.

Ключевые слова: самостоятельная работа, практические занятия, студент, самореализация.

Tsisaruk I. The main approaches to the problem of self-organization and preparation of future teachers of technology.

In the article basic approaches open up to the problem of organization of independent work of future specialists, the role of independent work is analysed on practical employments of technological disciplines.

Key words: independent work, practical employments, student, self-realization. 